\title{
Immunoglobulin G4-related disease masquerading as metastatic malignant melanoma of the choroid
}

\author{
Samreen Khanam 지, ${ }^{1}$ Ayushi Agarwal 다, ${ }^{1}$ Ruchi Goel 다, ${ }^{1}$ Ravindra Kumar Saran ${ }^{2}$
}

${ }^{1}$ Ophthalmology, Guru Nanak Eye Centre, Maulana Azad Medical College, New Delhi, India

${ }^{2}$ Pathology, Govind Ballabh Pant Institute of Postgraduate Medical Education and Research, New Delhi, India

\section{Correspondence to}

Professor Ruchi Goel; gruchi1@rediffmail.com

Accepted 17 March 2021
Check for updates

(C) BMJ Publishing Group Limited 2021. No commercial re-use. See rights and permissions. Published by BMJ.

To cite: Khanam $S$, Agarwal A, Goel R, et al. BMJ Case Rep 2021;14:e241605. doi:10.1136/bcr-2021-

241605

\section{DESCRIPTION}

Immunoglobulin G4-related disease (IgG4-RD) is an immune-mediated fibro-inflammatory condition known to have a diverse range of clinical presentation, involving single or multiple organs. The lesion, in all such cases, shows characteristic lymphoplasmacytic infiltration with fibrosis on histopathological analysis. The most commonly involved sites include pancreas and salivary glands. Other common manifestations are lymphadenopathy, sclerosing cholangitis, tubulointerstitial nephritis and retroperitoneal fibrosis. ${ }^{1}$ In ophthalmic clinical practice, IgG4-RD is usually encountered on tissue analysis of cases diagnosed with idiopathic orbital inflammatory disease. It may involve lacrimal gland (dacryoadenitis), sclera, extraocular muscles, optic nerve, trigeminal nerve and orbital bone. ${ }^{23}$ Elevated serum IgG4 levels maybe seen in many patients but is not diagnostic.

A 19-year-old girl presented with gradual painful loss of vision in the right eye for 2 months. The visual acuity was absence of light perception in the right eye, and 20/20 in the left eye. Slit lamp examination of the right eye showed an irregularly deep anterior chamber, with pigment deposition on the endothelium, and vitritis. Presence of a grade 4 vitritis precluded any visualisation of the posterior segment. The left eye examination was unremarkable. An ultrasound B-scan was suggestive of an intraocular lesion with heterogeneous echogenicity in the nasal part of the right globe. MRI showed an intraocular mass lesion, measuring $1.6 \times 1.6 \mathrm{~cm}$, in

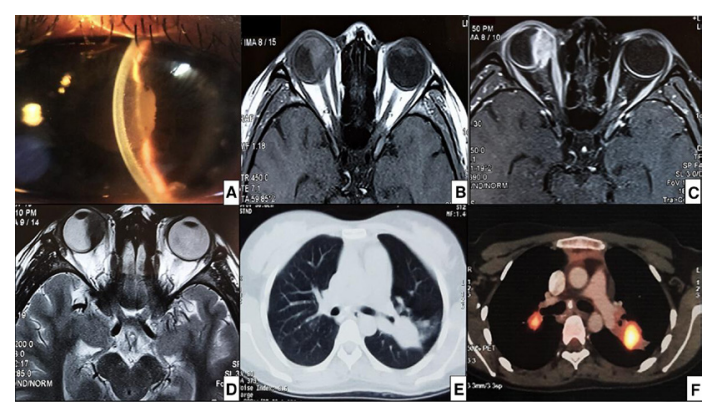

Figure 1 Clinicoradiological presentation. (A) Inflammation of the right eye, with uveitis, vitritis and irregular anterior chamber depth MRI showing an intraocular lesion (B) hyperintense on T1-weighted imaging, $(C)$ heterogeneous post-contrast enhancement, and (D) hypointense on T2-weighted imaging. (E) CT chest showing heterogeneously enhancing areas of consolidation with nodules (f) 18-fluorodeoxyglucose positron emission tomography/CT showing metabolically active fluorodeoxyglucose avid areas in the lung.

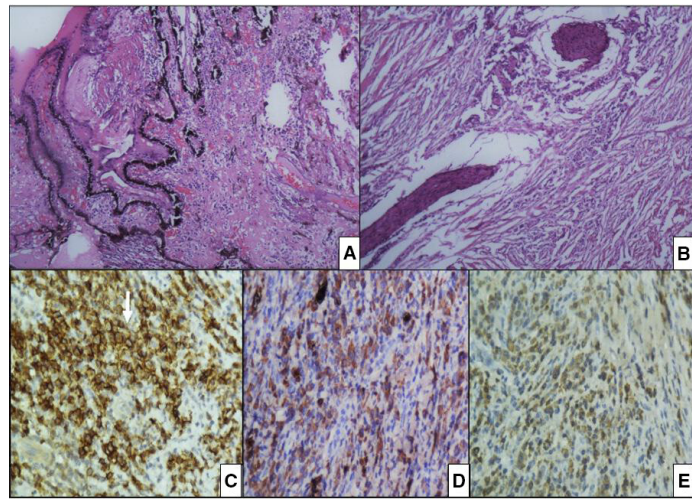

Figure 2 Histopathological specimen showing (A) $\mathrm{H} \& \mathrm{E} \times 4$ inflammation reaching upto the ciliary body (B) outer episcleral blood vessels and nerve twigs encircled by inflammation and dense fibrosis $(C) \times 40$ immunohistochemistry (IHC) staining positive for CD38 (intense positivity of plasma cells) (D) $\times 40 \mathrm{IHC}$ staining reveals positivity for IgG-secreting plasma cells $(E) \times 40$ IHC staining reveals clusters of IgG4-staining plasma cells (>50/high-power field).

the inferomedial part of the right globe. The lesion was hyperintense on T1-weighted imaging and hypointense on T2-weighted imaging, with heterogeneous post-contrast enhancement. Suspecting malignancy of the choroid, a whole-body CT scan was done to look for metastasis. It revealed heterogeneously enhancing areas of consolidation with few nodules in upper lobes of both the lungs. 18-fluorodeoxyglucose positron emission tomography/CT $\left({ }^{18} \mathrm{~F}-\mathrm{FDG}\right.$ PET/CT) showed increased metabolic activity in the lung lesions, and bilateral cervical (Level Ia, Ib, II, III and V) and mediastinal (right paratracheal, prevascular, subcarinal and right peribronchial) lymph nodes (figure 1). The patient was advised endobronchial biopsy of the lung lesion, but the procedure had to be deferred due to the prevailing COVID-19 situation at that point of time.

An enucleation of the right eye was considered as it was a painful blind eye, and a tissue analysis of the suspected malignancy was required. Histopathological examination of the tissue demonstrated a plasma-lymphocytic inflammatory infiltration with dense fibrosis and no evidence of malignancy(figure 2A,B). The plasma cells were positive for CD38 and IgG4, with >50 IgG4 + cells/highpower field (figure $2 \mathrm{C}-\mathrm{E}$ ). The serum IgG4 levels were found to be $215 \mathrm{mg} / \mathrm{dL}$ (normal $<135 \mathrm{mg} / \mathrm{dL}$ ), and the case was diagnosed as IgG4-RD. Immunosuppressive therapy (oral prednisolone $40 \mathrm{mg} / \mathrm{day}$ 
for 2 months tapered to a maintenance dose of $5 \mathrm{mg} / \mathrm{day}$ ) was initiated by the department of internal medicine, resulting in the resolution of the lung lesions. No involvement of the other eye was noted at any time.

Involvement of multiple organs is frequently seen in IgG4-RD and is likely to be mistaken for metastatic disease, as in this patient. Increased uptake on ${ }^{18} \mathrm{~F}$-FDG PET/CT at other sites in our case was due to coexisting systemic involvement in IgG4-RD.

\section{Patient's perspective}

I had severe pain and redness in my right eye. I could not see anything with the right eye. I was told that I may have a tumour and the eyeball would need removal. I got to know that the disease may have spread to other parts of my body as well. Fortunately, it did not turn out to be a tumour and hopefully, I shall recover following completion of my therapy.

\section{Learning points}

- Immunoglobulin G4--related disease can mimic metastatic malignant melanoma of the choroid. Therefore, a high index of clinical suspicion can enable better management outcomes.

- In cases of suspected metastatic neoplasm with areas of increased uptake on 18-fluorodeoxyglucose positron emission tomography/CT, alternative causes of increased metabolic activity must be considered.
As a matter of fact, a whole-body ${ }^{18} \mathrm{~F}$-FDG PET/CT is now being used to guide the selection of biopsy site in suspected cases of IgG4-RD and to monitor the disease activity and the response to treatment. ${ }^{4}$

To conclude, IgG4-RD can rarely masquerade as an intraocular malignancy. Timely diagnosis can aid appropriate management of such cases.

Contributors SK, RG and AA wrote the manuscript and edited the images. SK conceptualised the case report. RG and SK managed the patient and did the literature search. RKS helped in diagnosing the case and obtaining histopathological images. RG is the corresponding author and assumes responsibility for the case report.

Funding The authors have not declared a specific grant for this research from any funding agency in the public, commercial or not-for-profit sectors.

Competing interests None declared.

Patient consent for publication Obtained.

Provenance and peer review Not commissioned; externally peer reviewed.

\section{ORCID iDs}

Samreen Khanam http://orcid.org/0000-0002-6530-3390

Ayushi Agarwal http://orcid.org/0000-0002-0635-3275

Ruchi Goel http://orcid.org/0000-0001-6944-7466

\section{REFERENCES}

1 Lang D, Zwerina J, Pieringer H. IgG4-related disease: current challenges and future prospects. Ther Clin Risk Manag 2016;12:189-99.

2 Ebbo M, Patient M, Grados A, et al. Ophthalmic manifestations in IgG4-related disease: clinical presentation and response to treatment in a French case-series. Medicine 2017:96:e6205.

3 Andrew N, Kearney D, Selva D. IgG4-Related orbital disease: a meta-analysis and review. Acta Ophthalmol 2013;91:694-700.

4 Zhang J, Chen H, Ma Y, et al. Characterizing IgG4-related disease with 18F-FDG PET/CT: a prospective cohort study. Eur J Nucl Med Mol Imaging 2014;41:1624-34.

Copyright 2021 BMJ Publishing Group. All rights reserved. For permission to reuse any of this content visit

https://www.bmj.com/company/products-services/rights-and-licensing/permissions/

BMJ Case Report Fellows may re-use this article for personal use and teaching without any further permission.

Become a Fellow of BMJ Case Reports today and you can:

- Submit as many cases as you like

- Enjoy fast sympathetic peer review and rapid publication of accepted articles

- Access all the published articles

Re-use any of the published material for personal use and teaching without further permission

Customer Service

If you have any further queries about your subscription, please contact our customer services team on +44 (0) 2071111105 or via email at support@bmj.com.

Visit casereports.bmj.com for more articles like this and to become a Fellow 